\title{
Homenagem a Fidelis Policarpo Cabral de Almada
}

No dia 23 de setembro de 1982, em sessão solene realizada no Salão Nobre, o Doutor Fidelis Policarpo Cabral de Almada, ministro da Justiça de Guiné-Bissau, formado por esta Faculdade em 1962, foi saudado pelo Professor José Ignácio Botelho de Mesquita, titular de Direito Processual Civil da Faculdade de Direito da Universidade de São Paulo. A homenagem:

Ministro da Justiça da República da Guiné-Bissau

Excelentíssimo Senhor

\section{Dr. FIDELIS POLICARPO CABRAL DE ALMADA}

Fui incumbido por nosso Diretor, o eminente professor Vicente Marotta Rangel, de saudar Vossa Excelência em nome da E. Congregação desta Faculdade. Posso assegurar-lhe, Sr. Ministro, que esta honrosa incumbência constituiu para mim tarefa muita grata, como o seria a qualquer dos demais professores desta Casa.

Em dias como o de hoje, vemo-nos forçados a romper por um momento com a modéstia, a que obriga a tradição franciscana, e admitir o justificado orgulho com que abrimos as nossas portas para receber de volta, ainda que por tempo breve, mas coberto pelos sinais de sua luta e pelas marcas da sua vitória, um dos filhos ilustres desta Casa.

Faz agora 20 anos, pois foi em 1962, que Vossa Excelência concluiu nesta Faculdade o seu curso de bacharelado. O estudante que, então, aportara à nossa Casa, já havia percorrido um longo caminho, desde que deixara na distante Guiné, a sua querida Mansôa.

Um longo caminho já havia sido palmilhado, mas ainda era apenas o começo. Fora um começo difícil, como o é sempre, para quem traga sempre acesa dentro de si a chama da independência.

No entanto, porque a fundação desta Faculdade está vinculada à proclamação da independência do Brasil, e porque a história desta Academia, no que tem de perene, é indissociável da conquista da liberdade sob a lei, é razoável imaginar que, entrando então nesta 
Casa, tenha Vossa Excelência encontrado, ao pé de nossas arcadas, não só o calor da amizade e da compreensão, mas também o conforto d'alma que se experimenta ao chegar na própria morada.

Mais do que imaginar que assim tenha sido, posso dizer que gostaríamos todos, enormemente, assim tivesse sido o seu ingresso em nossa €scola. Nada há, na verdade, em que mais se tenham empenhados todos aqueles, alunos e professores desta Faculdade, que efetivamente se identificam com a história da Academia, do que na tarefa de vencer, diariamente, mais uma etapa da luta pelo direito. $\mathrm{E}$ uma tarefa difícil, bem o sabe Vossa Excelência. Não só pelos obstáculos que oferece, como também porque seus frutos tardam muito a amadurecer, sendo raro que possam ser saboreados por aqueles que, penosamente, os semearam. Exatamente por isso, em relação a cada aluno que sai desta Faculdade, ficamos aqui ansiando pelo momento de ver o dia em que a sua vitória pessoal, na defesa do direito e do justo, recompense a Faculdade por tudo aquilo que ela se esforça por ser.

O retorno de Vossa Excelência, hoje, tem para nós este sentido: de recompensa. E tanto maior, quando contemplamos, na sua totalidade, todo o caminho que se desenvolveu, unindo, estes dois extremos do seu tempo.

É um caminho em que se confundem a sua história e a história de seu país; em que se harmonizam, indistintamente, a sua independência e a independência do seu povo, de sua nação, hoje a República da Guiné-Bissau.

A sua presença nesta Casa é um penhor de sua estima por ela, que muito nos envaidece. É um traço de união estendido entre dois tempos, o passado e o presente, que nós gostaríamos de ver projetado no futuro.

Vossa Excelência, porém, aqui comparece não apenas nesta qualidade, para nós tão grata, de bacharel em Direito formado nesta Faculdade. Comparece também, em visita oficial, como Ministro de Estado, representando o seu país.

Traz para o nosso meio a possibilidade de uma colaboração no campo das instituições jurídicas.

(1)

Sua visita, também neste ponto, se revela motivo, para nós, de grande alegria.

Bem podemos compreender a magnitude dos problemas com que se defrontam as naçōes como a que Vossa Excelência representa quando transitam da condição de colônias para a de estados soberanos. E são ainda maiores quando têm de arcar com o peso de uma luta prolongada e, após a vitória, vêem a emergir, para a vida internacional, nurn momento em que até mesmo os Estados mais desenvolvidos se vêm a braços com uma crise econômica de proporções extremamente graves. 
O fato, no entanto, de constituir objeto de sua visita a esta Faculdade, o estudo das possibilidades de se estabelecer entre nós um intercâmbio cultural, é em sí mesmo auspicioso e nos permite alimentar. fundadas esperanças no futuro de seu país.

Assim pensamos por duas razões.

A primeira delas advém do fato de estar manifesta a preocupação da Guiné-Bissau com o ensino. Esta preocupação é condição primordial para o bom êxito, a longo prazo, de qualquer programa de governo.

As nações em vias de desenvolvimento e também as nações que já se preparam para deixar sua condição de Estados periféricos para ingressar na de Estados centrais, sofrem, de um modo geral, de deficiências crônicas no campo da educação, que as inibem de transpor a barreira do subdesenvolvimento ou vencer os espaços que as distanciam dos países centrais.

À feição de escusa para a falta de interesse maior pela educação do povo, é comum invocarem-se razões de natureza econômica que a história, contudo, no passar dos anos, tem revelado infundadas. Não porque não faltem, de fato, à estas nações os desejáveis recursos econômicos, mas porque os recursos existentes, ainda que parcos, costumam ser orientados para outras áreas, de menor prioridade, como ocorre com as verbas canalizadas para a manutenção de um aparelho estatal freqüentemente superdimensionado e, não raro, ineficiente, quando não para alimentar tendências armamentísticas ou ambiciosos planos de governo, pouco ou nada compativeis com as exigências mais prementes de cada povo.

A recuperação a que todos assistimos, dos países mais desenvolvidos, após terem tido suas economias destroçadas pela guerra, constitui uma demonstração insofismável de que as carências puramente econômicas não constituem, por si só, um obstáculo ao pleno desenvolvimento.

O que permitiu às nações desenvolvidas, em curto espaço de tempo, uma formidável recuperação econômica, assim como o que permitirá a elas, hoje, sentir menor grau do que os países periféricos da crise econômica que afeta o mundo inteiro e com maior intensidade as economias capitalistas, outra coisa não foi, como ainda agora não o será, senão o seu elevado nível cultural. O estágio cultural em que se colocam constitui, na verdade, a única garantia de uma resposta adequada, seja por parte do povo, seja por parte dos seus dirigentes, aos problemas que as crises econômicas lhes propõem.

Ao contrário dos países que há mais tempo alcançaram sua independência e que hoje se defrontam com o peso de inúmeros erros já cometidos no campo da educação, conta o seu país, a República de Guiné-Bissau, com a vantagem de estar criando algo inteiramente novo, com a vantagem de se encontrar neste momento magnífico de sua história que é o momento da criação; o momento da criação das 
condições para sua existência, no conserto das nações, como estado independente. É o momento de reunir e ordenar as magníficas forças de suas tradições ancestrais, cujo poder bem se revelou no valor com que se lançou o seu povo ao sacrifício demandado pela defesa de sua liberdade.

Daí podermos vislumbrar, Senhor Ministro, nas preocupações do governo que Vossa Excelência representa, que também são as de nossa Universidade, a semente e a promessa de verdadeiro desenvolvimento para o futuro da Guiné-Bissau.

Há ainda outra razão para nossa confiança no porvir de sua pátria. E 0 interesse que a sua visita revela no aprimoramento do ensino do Direito.

Há poucos dias tivemos ocasião de receber aqui, nesta mesma sala, um eminente jurista e filósofo italiano, o prof. NORBERTO BUBBIO, que escolheu como tema à sua aula uma velha pergunta: o que é melhor, o governo dos homens ou o governo das leis? O governo cuja atuação se reja por normas ditadas pelo próprio governante, ou um governo cuja atuação seja limitada por normas criadas por outrem, pelo povo, que o governante, por sua própria vontade, não possa alterar.

As duas alternativas sempre tiveram, ao longo da história da ciência política, defensores ilustres e adeptos fervorosos. Basta lembrar, o ideal do governo dos reis filósofos, esboçado na "República" de Platão, que ainda hoje continua sendo, no dizer de STONE "o preferido dos hierarcas, qualquer que seja o seu disfarce", (Ideal de Platão, "in" Suplemento Cultural do Jornal O Estado de S. Paulo, n 106, pág. 6).

De fato, como ainda acentuava BOBBIO naquela conferência, a experiência histórica tem demonstrado que, inobstante a excelência dos argumentos com que se possam, no plano teórico, justificar qualquer uma daquelas alternativas, o que se tem observado é que, onde se preferiu ao governo das leis, o governo dos homens, aí com maior facilidade transitaram para a tirania sistemas de governos que, na sua origem, decorreram de aspirações populares vitoriosas.

Conseqüentemente, a preocupação governamental com o ensino do direito já revela, de si só, a vocação para a construção de um sistema de governo que não se arreceia dos limites que a lei lhe possa impor e, bem ao contrário, manifesta a crença das virtudes de um governo que sirva lealmente às leis de sua nação.

Neste particular, aprofundando um pouco mais as reflexões que este tema sugere, é sempre conveniente ponderar, notadamente porque estamos diante de um projeto de intercâmbio cultural, que o fenômeno jurídico tanto tem de universal, no que tange à realização do ideal de Justiça, como de particular, no que respeita aos valores fundamentais que enformam a alma de cada nação.

O saber jurídico, enquanto expressão de uma experiência universal haurida ao longo dos séculos de luta pelo aperfeiçoamento do direito, 
constitui exigência que deve ser satisfeita por qualquer nação que pretenda alcançar para si própria o status de nação independente e livre. A transposição desse conhecimento para o plano do direito positivo há de se processar, contudo, sem conflito, antes com sagrado respeito, pelas leis e pelo costume revelados ao longo da história de cada povo.

A história de nossa Faculdade, como disse ao início, está firmada exatamente nesta convicção, pois foi da necessidade de criarmos o nosso direito, como exigência do nosso ideal de independência, que se fundaram os cursos jurídicos de São Paulo e Olinda. Precisamente por isto, Sr. Ministro, somos reconhecidos pela confiança que the inspiramos. Confiança não apenas no esforço que aqui desenvolvemos para o aperfeiçoamento das instituições jurídicas, mas principalmente no respeito que votamos à dignidade das leis e dos costumes, no que traduzem o que de mais profundo na alma de cada nação.

Como que enfeixando, em sua própria pessoa, todos esses valores, para nós tão caros, Vossa Excelência aqui se apresenta, mais do que como antigo aluno e Ministro de Estado, Vossa Excelência aqui se apresenta como Ministro que ocupa a Pasta da Justiça.

Esta condição empresta notável realce à sua presença entre nós.

Perdoe-me Vossa Excelência que, neste passo, eu me deixe levar por minha condição de processualista para confessar-lhe a convicção de que é exatamente perante o posto que Vossa Excelência ocupa, dadas as funções que na Guiné-Bissau lhe estão confiadas, que o fenômeno jurídico se revela no que tem de mais delicado e, por isto mesmo, de mais importante.

No direito e para o direito, não basta que se disponha de normas excelentes, porque o direito é acima de tudo experiência. $O$ que mais importa é a possibilidade concreta de se fazer realizar, em cada caso, de se fazer cumprir, a promessa do legislador, formulada na lei ou revelada no costume.

Esta possibilidade aumenta ou diminui na razão direta do nível de aptidão da organização judiciária, dos juízes individualmente considerados e das regras do processo; do seu nivel de aptidão, repito, a dar concreção às justas aspirações do povo, no que concerne à realização do direito.

No capítulo da história da independência de um país, Senhor Ministro, esta matéria transcende em importância a quaisquer outras. A idéia de independência implica a de liberdade diante do poder; traz consigo uma ânsia incontida de igualdade e de paz sob o direito, que somente a boa administração da Justiça pode satisfazer.

Sou eu mesmo testemunha dessas aspirações, como o são os versos, a um só tempo corajosos e tristes, de uma poesia que, em 1971, pouco 
antes, portanto, da independência, me foi entregue, em Moçambique, num encontro de que jamais me esquecerei. Lembro-me como se fosse hoje. Havia no ar uma certa tensão que o carinho envolvente de todos os participantes procurava dissipar. As conversas faziam ressurgir dentro de mim, como retiradas de um passado bem mais que secular, as falas que se deviam ouvir aqui no Brasil nos tempos imediatamente anteriores à nossa independência. A lembrança da comoção que então me avassalou, ainda hoje me emociona.

A poesia se intitulava "Esta Gente". Seus versos assim diziam:

Esta gente cujo rosto

às vezes luminoso

$E$ outras vezes tosco

Ora me lembra escravos

Ora me lembra reis,

Faz nascer meu gosto

De luta e de combate,

Pois esta gente tem

$O$ rosto desenhado

Por paciência e fome.

$\hat{E}$ a gente em quem

Um país ocupado escreve o seu nome.

$E$ em frente desta gente,

Ignorada e pisada

Como a pedra do chão

$\mathbf{E}$ mais do que a pedra

Humilhada e calcada,

Meu canto se renova

E recomeça a busca

Dum país liberto

Duma vida limpa

E dum tempo justo.

A grandeza de sua missão, Senhor Ministro, só se iguala à magnitude das responsabilidades que pesam sobre os ombros de Vossa Excelência.

Exatamente por isto, sente-se honrada esta Faculdade por ver um seu antigo aluno escolhido para o desempenho de tão alta função. E mais honrada ainda, por tê-lo hoje em nossa Casa, a percorrer novamente os mesmos caminhos que guardam ainda as lembranças de seus passos.

Senhor Ministro FIDELIS POLICARPO CABRAL DE ALMADA, em nome da E. Congregação da Faculdade de Direito da Universidade de São Paulo, quero expressar-lhe as nossas boas vindas, as nossas homenagens, por tudo o que representa, assim como os nossos votos de felicidade tanto para Vossa Excelência pessoalmente como para o seu país, a República da Guiné-Bissau! 